Greer, García-Reidy, and research assistants have now analyzed over five hundred manuscripts, creating 765 hand-description records, adding images of manuscripts and live links to any that can be viewed digitally through library collections. We have identified the hands of ninety-five dramatists, major and minor, of sixty-eight copyists, and of over 350 hands of copyists yet to be named. We work from the known toward the unknown, first analyzing manuscripts signed by the writer or otherwise identified as his or hers, then dated but unsigned manuscripts. Other accomplishments to date include: I) identifying a Lope de Vega play presumed lost; 2) identifying the authors of various manuscripts previously listed as anonymous; 3) correcting incorrect bibliographic and cataloging information of manuscripts in various libraries; 4) identifying and explaining the nature of manuscripts that were made as actors' copies rather than for or by company owners or prompters; 5) bringing to light the intervention of censors and their effects on some texts; 6) identifying a substantial group of professional copyists who made manuscripts for sale to theater companies and readers; and 7) identifying the writers of several manuscripts made by "memoriones" who memorized the text at a play's performance and wrote it out for sale to a competing theater company.

In 2013, our aims (in addition to expanding the number of analyzed manuscripts) are to perfect the writer identification and verification software and to add automatic methods to match a manuscript image, character by character, to a computer transcription of it, thereby also matching manuscripts to each other through their common transcriptions. These matches will provide labeled training pairs of letters written by the various hands. We will then use these pairs for machine-verified and quantified writer identification. We also hope thereby to advance toward semi-automatic transcription of manuscripts by any individual hand so processed. Finally, we intend to explain how our cyber-paleography techniques can be put to use by literary scholars and historians dealing with document collections in other languages and cultures beyond early modern Spain.

\title{
Digital Renaissance Editions
}

BRETT D. HIRSCH

ew scholars, students, and members of the public have ready access to the
rare book and manuscript collections of the world's elite research libraries 
and museums. Fewer still have digital access to these collections through expensive commercial database subscriptions. To study, teach, or perform a play requires access to its text; but access alone to the original-whether in facsimile, transcription, or in situ-is not enough: to make centuries-old plays intelligible to modern readers requires the dedicated work of expert scholars to establish authoritative texts and provide necessary annotations and commentary. While over eight hundred English plays survive from the early modern period, the vast majority remain inaccessible to modern readers. Many did not appeal to eighteenth-and nineteenth-century sensibilities or conform to antiquated notions of modesty, while literary critics dismissed others as unpoetic without consideration of their value as theater or as social documents. As a result, there are few, if any, modern editions of these plays.

Shakespeare's works account for less than five percent of the surviving early English plays, and yet modern editions abound, catering to a dizzying variety of readers in multiple languages and media formats. As only one out of some two hundred, Shakespeare represents less than one percent of the dramatists (amateur and professional) active during this period. The drama of Shakespeare's immediate predecessors, contemporaries, and successors remains undervalued, under-taught, underperformed, unread, and unknown. It is time to stand up for the ninety-nine percent.

This is the call-to-arms of Digital Renaissance Editions, a project to publish multimedia scholarly editions of early English drama and make them freely available online to a worldwide audience for reading, teaching, and performance. To complement and enrich the editions, the project also includes a Performance Database comprising a growing collection of multimedia performance materials related to early English drama as well as a Critical Companion comprising freshly commissioned peer-reviewed essays on topics relevant to the study of the plays and their contexts. In so doing, the project aims to facilitate greater global access to and appreciation of early English drama and its historical, cultural, and theatrical contexts.

To achieve these ambitious goals, Digital Renaissance Editions relies upon the expertise of dedicated international scholars, theater professionals, and software developers working with the highest standards of scholarship and usability in mind. An ongoing partnership with the critically acclaimed Internet Shakespeare Editions plays a crucial role, as the projects share the same publishing platform, virtual infrastructure, and future vision.

The project publishes editions of early English plays by dramatists other than Shakespeare-some for the first time-prepared specifically for the 
electronic medium by a team of international scholars and editors. Editions typically include photo-facsimiles (in color, where available) and diplomatic transcriptions of early textual witnesses (whether print or manuscript) as well as modern-spelling texts with full critical apparatus (e.g., annotations, commentary, collations of textual variants and historical editions). Editions also include critical and textual introductions, supplementary and supporting materials in various media, and support for integration with other digital projects, such as DEEP: Database of Early English Playbooks, Lexicons of Early Modern English, Lost Plays Database, and the Map of Early Modern London. The Critical Companion of essays on topics relevant for a deeper understanding of the drama and its various contexts complements the editions, covering a range of topics in depth and including multimedia content (where appropriate) to serve the needs of scholars and students alike. The Performance Database similarly provides a global record of current and historical performances of early English drama, with multimedia performance materials offering a dynamic view of the interpretation of the plays in different times, cultures, media, and spaces. All content is subject to rigorous peer review to ensure scholarly quality.

Distinguished editorial and advisory boards oversee the academic development of Digital Renaissance Editions, with members from institutions in Australia, Canada, the Netherlands, New Zealand, the United Kingdom, and the United States. A coordinating editor (Brett D. Hirsch) and three general textual editors (Eleanor Lowe, Sarah Neville, and Will Sharpe) lead the editorial group, whose members include Michael Best, Hugh Craig, Janelle Jenstad, Ian Lancashire, Helen Ostovich, and Chris Wortham. The twenty-two eminent international scholars serving on the advisory board include David Bevington, A.R. Braunmuller, Richard Dutton, Jean E. Howard, MacDonald P. Jackson, David Scott Kastan, Kate McLuskie, Stephen Orgel, and many more. An equally distinguished board of global performance experts (e.g., Alexander C.Y. Huang, Peter Kirwan), dramaturgs and practice-based researchers (e.g., Terri Bourus, Peter Cockett, Jennifer Roberts-Smith, Eleanor Rycroft), secondary drama educators (e.g., Perry Mills), and directors for stage and screen (e.g., Alex Cox, Paige Newmark) oversees the Performance Database.

Digital Renaissance Editions, together with Internet Shakespeare Editions and Queen's Men Editions, seeks to make electronic scholarly editions of the drama of Shakespeare, his predecessors, contemporaries, and successors freely available for future generations of readers, scholars, students, and actors. At the time of writing, the editorial board has approved twenty-four proposed 
editions, with other proposals currently under consideration. The project is investigating the possibility of establishing a series of affordable print editions, derived from the electronic versions, designed to meet the needs of university and college students. Joost Daalder's edition of The Honest Whore, Parts One and Two will inaugurate Digital Renaissance Editions at its launch in fall 2013. Prospective editors or contributors to any aspect of the project are encouraged to contact the coordinating editor.

W O R K S C I T E D

DEEP: Database of Early English Playbooks. Ed. Alan B. Farmer and Zachary Lesser. U Pennsylvania, 2007-present. <http://deep.sas.upenn.edu/>.

Digital Renaissance Editions. Coord. Ed. Brett D. Hirsch. U Western Australia and Internet Shakespeare Editions, 2006-present. <http://digitalrenaissance.uvic.ca/>.

Internet Shakespeare Editions. Coord. Ed. Michael Best. U Victoria, I996-present. <http:// internetshakespeare.uvic.ca/>.

Lexicons of Early Modern English. Ed. Ian Lancashire. U Toronto Library and U Toronto P, 2006-present. <http://leme.library.utoronto.ca/>.

Lost Plays Database. Coord. Ed. Roslyn L. Knutson and David McInnis. U Melbourne, 2009-present. <http://www.lostplays.org/>.

Map of Early Modern London. Gen. Ed. Janelle Jenstad. U Victoria, 2003-present. <http:// mapoflondon.uvic.ca/>.

Queen's Men Editions. Gen. Ed. Helen Ostovich. McMaster U, U Toronto, and Internet Shakespeare Editions, 2006-present. <http://qme.internetshakespeare.uvic.ca/>.

\title{
APPOSITIONS at Work:
}

\section{Reflections on Open-Access Publishing}

\author{
W. SCOTT HOWARD
}

$\mathrm{T}$ his essay concerns contributions to the field since 2008 from the peerreviewed, MLA-indexed, EBSCO-distributed e-journal, APPOSITIONS: Studies in Renaissance/Early Modern Literature E Culture (http://appositions.blogspot.com), of which I am the founding editor. ${ }^{1}$ APPOSITIONS is an open-access, annual, independently managed journal that aims to build bridges among different communities: Renaissance scholars and early modernists; literary and cultural critics; university/college faculty and independent scholars; and disparate academic societies. ${ }^{2}$ Print journals reach those audiences as well, of course, but e-journals can build their communities in ways 